\title{
Diversity and habitat preferences of Carabidae and Staphylinidae (Coleoptera) in two agroecosystems
}

\author{
Ivan Carlos Fernandes Martins ( ${ }^{(*)}$; Francisco Jorge Cividanes (2); Sergio Ide (3); Gianni Queiroz Haddad (²) \\ (') Universidade Federal Rural da Amazônia, Campus de Capanema, Rua João Pessoa s/n, 68700-030 Capanema (PA), Brasil. \\ (2) UNESP, Faculdade de Ciências Agrárias e Veterinárias, Departamento de Fitossanidade, Via de acesso Donato Castellane s/n, \\ 14884-900 Jaboticabal (SP), Brasil. \\ (3) Instituto Biológico, Centro de Pesquisa e Desenvolvimento de Sanidade Vegetal, Avenida Conselheiro Rodrigues Alves, 1252, \\ 04014-002 São Paulo (SP), Brasil. \\ (*) Corresponding author: carabideos@yahoo.com.br
}

Received: Feb. 24, 2012; Accepted: Nov. 7, 2012

\begin{abstract}
The present study had as objective determine the diversity and abundance of adults Carabidae and Staphylinidae in two areas, constituted by forest fragment and soybean/corn crops under conventional tillage and no-tillage systems and to analyze the distribution and preference of those beetles for the habitat. The beetles were sampled with 48 pitfall traps. In both experimental areas, two parallel transects of pitfall traps were installed. Each transect had $100 \mathrm{~m}$ in the crop and $100 \mathrm{~m}$ in the forest fragment. Four traps were close to each other $(1 \mathrm{~m})$ in the edge between the crop and the forest fragment, the other traps were installed each $10 \mathrm{~m}$. The obtained data were submitted to the faunistic analysis and the preference of the species by habitat was obtained by cluster analysis. The results demonstrated that the type of crop system (conventional tillage or no-tillage) might have influenced the diversity of species of Carabidae and Staphylinidae. The cluster analysis evidenced that the carabids may prefer a specific habitat. In the present study, the distribution of carabids and staphylinids in the three habitats showed that these beetles have potential to be dispersed at great distances inside the crop.
\end{abstract}

Key words: ground beetles, rove beetles, no-tillage systems, forest fragment, edge.

\section{Diversidade e preferência de habitat de Carabidae e Staphylinidae (Coleoptera) em dois agroecossistemas}

\begin{abstract}
Resumo
Este estudo teve como objetivo determinar a diversidade e abundância de adultos de Carabidae e Staphylinidae em duas áreas, constituídas por fragmentos florestais e culturas de soja/milho sob sistemas de plantio convencional e direto, e analisar a distribuição e a preferência desses insetos para o habitat. Os besouros foram amostrados com o uso de 48 armadilhas de solo do tipo Pitfall. Em ambas as áreas experimentais, foram instalados dois transectos paralelos de armadilhas; cada transecto teve $100 \mathrm{~m}$ na culturas e $100 \mathrm{~m}$ no fragmento florestal. Na borda entre a cultura e o fragmento de floresta foram instaladas quatro armadilhas, que ficaram distantes entre si por $1 \mathrm{~m}$ e as outras armadilhas, a cada 10 m. Os dados obtidos foram submetidos à análise faunística e a preferência das espécies para o habitat foi obtida pela análise cluster. Pelos resultados, observa-se que o tipo de sistema de cultivo (convencional ou plantio direto) pode ter influenciado a diversidade de espécies de Carabidae e Staphylinidae. A análise de cluster evidenciou que os carabídeos tiveram preferência por um habitat específico. Neste estudo, a distribuição de carabídeos e estafilinídeos nos três habitats mostraram que estes besouros têm potencial para se dispersarem em grandes distâncias no interior da cultura.
\end{abstract}

Palavras-chave: Carabídeos, estafilinídeos, sistemas de plantio direto, fragmento florestal, borda.

\section{INTRODUCTION}

The diversity and abundance of insect predators in agricultural areas are affected by the type of agriculture and by the presence of natural habitats (Kromp, 1989; Kromp, 1999; PfiffNer and LuKa, 2000). Natural habitat is an important component of agroecosystems because it encourages insect predators dispersal (THomas et al., 1991), an important component of sustainable agriculture (Altieri et al., 2003). Furthermore, the absence of natural habitats near agricultural systems limits the potential of natural enemies in pest control (CoOMBES and Sotherton, 1986; Thomas et al., 1991).

Predators are important because they persist in crops during periods of low pest density and can prevent early season build-up of pest numbers (CURRY, 1993). Ground beetles (Carabidae) and rove beetles (Staphylinidae) are common generalist predators in agricultural soils (Екsснмітт et al., 1997). Carabids feed on ants, aphids, caterpillars, insect eggs, springtails and 
mites, and staphylinids feed on small nematodes, mites and collembola (Екsснмітт et al., 1997). They so can limit some prey populations in agroecosystems (EDWARDS et al., 1979; Kromp, 1999; LANG et al., 1999).

Natural refuges have a positive influence on natural enemy populations in temperate climates and benefit adjacent agricultural crops (Thomas et al., 1991; Dennis and FrY, 1992; Thomas et al., 2002; Collins et al., 2002; Collins et al., 2003; Fiedler and LANDis, 2007). In Brazil, a few studies have been done on the influence of natural refuges on the diversity, abundance and distribution of natural enemies in agricultural crops. Vegetation coverage in perennial crops increases the number of natural enemies (FADINI et al., 2001; Altieri et al., 2003). Moreover, the use of plants in the field margins and the use of native plants attract natural enemies to agricultural crops (MACEDo and Martins, 1998; Gonçalves and Souza-Silva, 2003; Silveira et al., 2005; Bellini et al., 2005; Demite and Feres, 2005).

An understanding of the composition and distribution of insect predator species and of their habitat preferences is fundamental to determine whether biological control can be improved by habitat manipulation (Clark et al., 1997; Holland et al., 1999). In this study, the diversity and abundance of adult Carabidae and Staphylinidae in forest fragments and in conventional tillage and no-tillage crops (soybean/corn) were investigated to analyze the distribution and preference of those beetles for those habitats.

\section{MATERIAL AND METHODS}

Field work was performed during the 2004/2005, 2005/2006 and 2006/2007 seasons, in two study areas located in the Guaíra county, State of Sáo Paulo, Brazil. Both were comprised of a forest fragment adjacent to an agricultural crop (soybean, Glycine max L. and corn, Zea mays L.).

Experimental area 1 was located in the "Barracão" farm $\left(20^{\circ} 21^{\prime} 18^{\prime \prime} S\right.$ and $\left.48^{\circ} 14{ }^{\prime} 47^{\prime \prime} \mathrm{W}\right)$. The plot was 88.6 ha and was subjected to no-tillage farm practices with soybean-corn rotation for 10 years prior to our study. There is a 48 hafragment of seasonal semideciduous forest adjacent to the plot. The soybean was cultivated with $0.5 \mathrm{~m}$ row spacing. In the off-season, corn was cultivated with $0.8 \mathrm{~m}$ row spacing.

Experimental area 2 was located in the "Mangues" farm, $\left(20^{\circ} 19^{\prime} 32^{\prime \prime} \mathrm{S}\right.$ and $\left.48^{\circ} 15^{\prime} 06^{\prime \prime} \mathrm{W}\right)$ approx. $2 \mathrm{~km}$ from the experimental area 1 . The plot was 12 ha and was subjected to conventional tillage practices with soybean-corn rotation. There is a 6-ha fragment of seasonal semideciduous forest adjacent to the plot. The soybean was cultivated with $0.5 \mathrm{~m}$ row spacing. In the off-season, corn was cultivated with $0.8 \mathrm{~m}$ row spacing.

Beetles were collected using pitfall traps $(500 \mathrm{~mL})$ containing a mixture of water $(150 \mathrm{~mL})$, formaldehyde (1\%) and some drops of neutral detergent. Pitfall traps were made of plastic cups $(80 \mathrm{~mm}$ diameter x $140 \mathrm{~mm}$ height) set in another plastic cup with holes in the base to drain the rain water. Each trap was covered with plastic (15 $\mathrm{cm}$ diameter) about $3 \mathrm{~cm}$ above the plastic cup.

In both experimental areas, two parallel transects of pitfall traps were installed. Transects were $10 \mathrm{~m}$ apart from one another. Each transect was $200 \mathrm{~m}$ in length, with $100 \mathrm{~m}$ in the crop and $100 \mathrm{~m}$ in the forest fragment. Four traps were $1 \mathrm{~m}$ apart from one another in the edge between the crop and the forest fragment and the other traps were each $10 \mathrm{~m}$ apart from one another. There were 48 traps in total (Figure 1).

Sampling was done twice a month during the growing season and once a month in the off-season (winter), from November $25^{\text {th }}, 2004$ to April 26 ${ }^{\text {th }}, 2007$, for a total of 44 sampling dates. The traps were kept in the field for one week, then removed and taken to the laboratory to screen and to identify the beetles. For identification a dichotomous key and comparison with the existing collections at the Museum of Zoology, Universidade de São Paulo and the Museum of Entomology, Instituto Biológico de São Paulo were used.

Data were analyzed using the faunistic software Anafau, and dominance, abundance, frequency and constancy were determined. Dominant species had the largest faunistic indexes for frequency, constancy, abundance and dominance (Silveira Neto et al., 1995).

Preference of a species for a habitat was determined by cluster analysis (Jaccard distance) (KREBS, 1999). This kind of analysis is used to gather the species by family (Carabidae or Staphylinidae) according to the position of the traps in the transect, which means, identifying the species as their preference for the habitat: species of forest fragment, crop and/or border. When two or more individuals had been captured during the whole sampling period, they were included in the analysis. This reduced the effect of species present in low quantities on the results. The species that were observed in fewer than five traps were considered rare and were also removed from the analyzed data following the methodology of BEDFORD and UsHER (1994).

The distribution of a species along of transects was subjected to cluster analysis. This distribution was used to verify the distance that the species were found in each habitat and if this happens preferably at a certain distance.

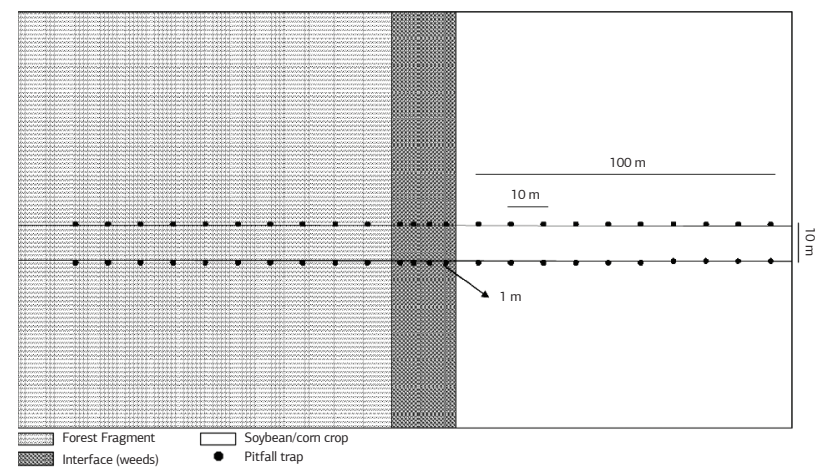

Figure 1. Arrangement of pitfall traps in the experimental areas. 


\section{RESULTS AND DISCUSSION}

In experimental area 1 (forest fragment and soybean/corn crop under no-tillage system), 47 species of Carabidae (800 specimens $/ 79.8 \%$ of total collected) and 32 of Staphylinidae (203/20.2\%) were captured (Table 1). In experimental area 2 (forest fragment and soybean/ corn crop under conventional tillage system), 38 species of Carabidae (1010 specimens/94.1\% of total collected) and 18 Staphylinidae (63/5.9\%) were captured (Table 2). The results demonstrated that the type of crop system might have influenced the diversity of species these beetles. According to House and Stinner (1983), the soil of soybean crops under no-tillage systems support a higher density and diversity of arthropods compared to in the soil of soybean crops under conventional tillage systems. Thomazini and Thomazini (2000) and Pichancourt et al. (2006) reported that the border effect and the size of the fragment could interfere in the diversity of insects, especially ground beetles. This is supported by our results in the area under no-tillage system, which had a forest fragment eight times larger than area under conventional tillage system and had a higher diversity of Carabidae and Staphylinidae species.

Among dominant carabids, Scarites sp.1, Abaris basistriata Chaudoir, 1873, Odontocheila nodicornis (Dejean, 1825), Calosoma granulatum Perty, 1830 and Loxandrus sp.1 were dominant in both areas, while Scarites sp.2, Tetracha brasiliensis Kirby, 1818, Selenophorus seriatoporus Putz, 1878, Pentacomia cupricollis Kollar, 1836, and Selenophorus sp.1 were dominant only in the area under no-tillage system (Tables 1 and 2). The number of dominant Staphylinidae was lower than dominant Carabidae. The dominant Staphylinidae were Staphylinidae ind.2, Xantholinini sp.1 and Eulissus chalybaeus Mannerheim, 1830 (Table 1); all in forest fragment and soybean/corn under no-tillage system.

Concerning the species preference to the habitat, only Carabidae species were selected by the criteria used. In the forest fragment and soybean/corn crop under notillage system, most of the species were gathered as crop and edge species or just as crop, being in a smaller number than the ones related to forest fragment (Figure 2). The number of species associated with the forest fragment was largest in conventional tillage system (Figure 3 ). These results demonstrated that, in the area under conventional system, carabids preferred the forest fragment. Thus, the structure of the vegetation is fundamental to the composition and distribution of ground beetles species (FrENCH and Elliott, 1999; Weibull and Östman, 2003).

Carabids are generalists in crops and in natural habitats (Thiele, 1977; French and Elliott, 1999; Fournier and Loreau, 1999). The cluster analysis showed that $A$. basistriata did not show a preference for a specific habitat in either experimental area, being considered a generalist with respect to habitat preference (Figures 2 and 3). C. granulatum and Scarites sp. 1 preferred soybean and corn crops under no-tillage system and was distributed until edge with the forest fragment. Those species, in the area under conventional tillage system, were limited just in the annual crop (Figures 2 and 3).

In the area under no-tillage system, $P$. cupricollis, T. brasiliensis and two species of the genus Scarites preferred the soybean and corn crop, being distributed until edge between the crop and the forest fragment. However, O. nodicornis and Loxandrus sp. 1 preferred the forest fragment (Figure 2). In the area under conventional tillage system, S. seriatoporus, Loxandrus sp. 1 and $O$. nodircornis preferred the forest fragment, being distributed up to the edge with the soybean and corn crop (Figure 3). The edge between the crop and the forest fragment was used by species with a preference for the crop and for the forest fragment.

Abaris basistriata, a habitat generalist, was distributed from the edge up to $100 \mathrm{~m}$ into the crop and 100 $m$ into the forest fragment. However, the distribution of $A$. basistriata differed among the experimental areas. In the area under no-tillage system, it was concentrated in the edge between crop and forest fragment. In the area under conventional tillage system, it was concentrated in the edge and up to $100 \mathrm{~m}$ into the forest fragment (Figures 4 and 5).

Odontocheila nodicornis and Loxandrus sp. 1 were distributed from the edge to $100 \mathrm{~m}$ in the forest fragment in both experimental areas (Figures 4 and 5). S. seriatoporus was concentrated in the edge between fragment forest and crops under conventional tillage system (Figure 5).

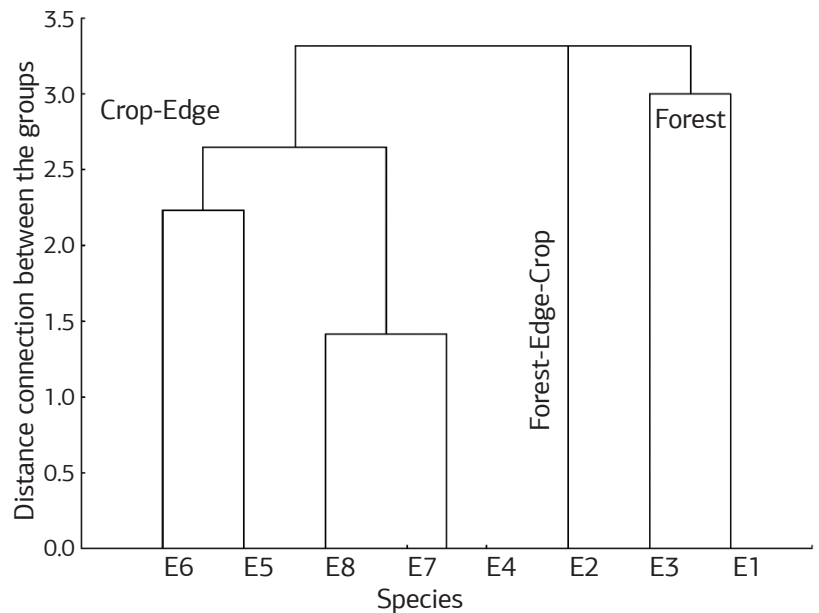

Figure 2. Cluster analysis dendrogram of species Carabidae depending on the position of the trap. Euclidian distance. No-tillage system-2004/2007. E1: Odontocheila nodicornis, E2: Abaris basistriata, E3: Loxandrus sp.1, E4: Scarites sp.1, E5: Pentacomia curpricollis, E6: Calosoma granulatum, E7: Scarites sp.2, E8: Tetracha brasiliensis. 
Table 1. Carabidae and Staphylinidae collected in areas of forest fragment and soybean crop in no-tillage system according to dominance (D), abundance (A), frequency (F) and constancy (C). Guaíra county, State of São Paulo, Brazil - 2004/2007

\begin{tabular}{|c|c|c|c|c|c|c|}
\hline Species/Family & Number of specimens & $\%$ & D & A & $\mathbf{F}$ & C \\
\hline \multicolumn{7}{|l|}{ Carabidae } \\
\hline Scarites sp.2 & 152 & 15.2 & D & $\mathrm{ma}$ & MF & W \\
\hline Scarites sp.1 & 128 & 12.8 & $\mathrm{D}$ & $\mathrm{ma}$ & MF & W \\
\hline Abaris basistriata Chaudoir, 1873 & 97 & 9.7 & D & ma & MF & W \\
\hline Tetracha brasiliensis Kirby, 1818 & 91 & 9.1 & $\mathrm{D}$ & $\mathrm{ma}$ & MF & W \\
\hline Selenophorus seriatoporus Putz, 1878 & 66 & 6.6 & $\mathrm{D}$ & ma & MF & W \\
\hline Loxandrus sp.1 & 57 & 5.7 & $\mathrm{D}$ & $\mathrm{ma}$ & MF & W \\
\hline Pentacomia cupricollis Kollar, 1836 & 46 & 4.6 & $\mathrm{D}$ & $\mathrm{ma}$ & MF & W \\
\hline Calosoma granulatum Perty, 1830 & 27 & 2.7 & $\mathrm{D}$ & $\mathrm{ma}$ & MF & W \\
\hline Odontocheila nodicornis (Dejean, 1825) & 19 & 1.9 & $\mathrm{D}$ & $\mathrm{a}$ & MF & W \\
\hline Selenophorus sp.1 & 19 & 1.9 & $\mathrm{D}$ & $\mathrm{a}$ & MF & W \\
\hline Selenophorus alternans Dejean, 1829 & 13 & 1.3 & D & c & $\mathrm{F}$ & $\mathrm{Y}$ \\
\hline Loxandrus subvittatus Straneo, 1953 & 13 & 1.3 & $\mathrm{D}$ & $c$ & $\mathrm{~F}$ & $\mathrm{Y}$ \\
\hline Galerita occidentalis (Olivier, 1795) & 5 & 0.5 & ND & d & $\mathrm{PF}$ & Z \\
\hline Tetragonoderus laevigatus Chaudoir, 1876 & 5 & 0.5 & ND & d & PF & Z \\
\hline Lebiini sp.1 & 5 & 0.5 & ND & d & PF & Z \\
\hline Stratiotes sp.1 & 4 & 0.4 & ND & r & $\mathrm{PF}$ & Z \\
\hline Sphalera plaumanni Liebke, 1939 & 4 & 0.4 & ND & $r$ & PF & Z \\
\hline Apenes marginalis Dejean, 1831 & 4 & 0.4 & ND & $r$ & PF & Z \\
\hline Athrostictus sp.1 & 3 & 0.3 & ND & r & PF & Z \\
\hline Tichonilla festiva (Tschitscherine, 1898) & 3 & 0.3 & ND & $r$ & PF & Z \\
\hline Lebiini sp.2 & 3 & 0.3 & ND & $r$ & $\mathrm{PF}$ & Z \\
\hline Pterostichini sp.1 & 3 & 0.3 & ND & $r$ & PF & Z \\
\hline Cymindis sp.1 & 3 & 0.3 & ND & $r$ & $\mathrm{PF}$ & Z \\
\hline Scarites sp. 3 & 2 & 0.2 & ND & $r$ & PF & Z \\
\hline Carabidae ind. 1 & 2 & 0.2 & ND & $r$ & PF & Z \\
\hline Pelecium brasiliense Straneo, 1962 & 2 & 0.2 & ND & $r$ & $\mathrm{PF}$ & Z \\
\hline Carabidae ind.2 & 2 & 0.2 & ND & $r$ & PF & Z \\
\hline Carabidae ind.3 & 2 & 0.2 & ND & $r$ & $\mathrm{PF}$ & Z \\
\hline Polpochila impressifrons Dejean, 1831 & 2 & 0.2 & ND & $r$ & PF & Z \\
\hline Notiobia sp.2 & 1 & 0.1 & ND & $r$ & $\mathrm{PF}$ & Z \\
\hline Notiobia sp.1 & 1 & 0.1 & ND & $r$ & $\mathrm{PF}$ & Z \\
\hline Pelecium foveicolle Chaudoir, 1866 & 1 & 0.1 & ND & r & $\mathrm{PF}$ & Z \\
\hline Lebiini sp.3 & 1 & 0.1 & ND & $r$ & $\mathrm{PF}$ & Z \\
\hline Scarites sp. 4 & 1 & 0.1 & ND & r & $\mathrm{PF}$ & Z \\
\hline Carabidae ind.4 & 1 & 0.1 & ND & $r$ & $\mathrm{PF}$ & Z \\
\hline Barysomus punctatostriatus Emden, 1949 & 1 & 0.1 & ND & r & $\mathrm{PF}$ & Z \\
\hline Carabidae ind.5 & 1 & 0.1 & ND & $r$ & $\mathrm{PF}$ & Z \\
\hline Carabidae ind. 8 & 1 & 0.1 & ND & $r$ & $\mathrm{PF}$ & Z \\
\hline Carabidae ind.9 & 1 & 0.1 & ND & $r$ & $\mathrm{PF}$ & Z \\
\hline Notiobia cupripennis (Germar, 1824) & 1 & 0.1 & ND & r & $\mathrm{PF}$ & Z \\
\hline Selenophorus sp.2 & 1 & 0.1 & ND & $r$ & $\mathrm{PF}$ & Z \\
\hline Carabidae ind.6 & 1 & 0.1 & ND & $r$ & PF & Z \\
\hline Carabidae ind.10 & 1 & 0.1 & ND & $r$ & PF & Z \\
\hline Helluomorphoides squiresi (Chaudoir, 1872) & 1 & 0.1 & ND & $r$ & PF & Z \\
\hline Carabidae ind.11 & 1 & 0.1 & ND & $r$ & $\mathrm{PF}$ & Z \\
\hline Carabidae ind.7 & 1 & 0.1 & ND & r & $\mathrm{PF}$ & Z \\
\hline Carabidae ind.20 & 1 & 0.1 & ND & $r$ & PF & Z \\
\hline Total Carabidae & 800 & 79.8 & & & & \\
\hline \multicolumn{7}{|l|}{ Staphylinidae } \\
\hline Staphylinidae ind.2 & 44 & 4.4 & $\mathrm{D}$ & $\mathrm{ma}$ & MF & W \\
\hline Staphylinidae ind. 1 & 37 & 3.7 & $\mathrm{D}$ & $\mathrm{ma}$ & MF & $\mathrm{Y}$ \\
\hline Xantholinini sp.1 & 34 & 3.4 & $\mathrm{D}$ & $\mathrm{ma}$ & MF & W \\
\hline Eulissus chalybaeus Mannerheim, 1830 & 28 & 2.8 & $\mathrm{D}$ & ma & MF & W \\
\hline Staphylinidae ind.5 & 10 & 1.0 & ND & $c$ & $\mathrm{~F}$ & Y \\
\hline Staphylinidae ind.3 & 8 & 0.8 & ND & C & $\mathrm{F}$ & $Y$ \\
\hline
\end{tabular}


Table 1. Continuation

\begin{tabular}{|c|c|c|c|c|c|c|}
\hline Species/Family & Number of specimens & $\%$ & D & A & $\mathbf{F}$ & C \\
\hline Glenus chrysis (Gravenhorst, 1806) & 5 & 0.5 & ND & $d$ & $\mathrm{PF}$ & Z \\
\hline Smilax pilosa (Fabricius, 1787) & 5 & 0.5 & ND & $d$ & $\mathrm{PF}$ & Z \\
\hline Staphylinidae ind.9 & 3 & 0.3 & ND & $\mathrm{r}$ & PF & Z \\
\hline Staphylinidae ind.10 & 2 & 0.2 & ND & $r$ & PF & Z \\
\hline Renda formicarius (Laporte de Castelnau, 1835) & 2 & 0.2 & ND & $\mathrm{r}$ & PF & Z \\
\hline Xantholinini sp.2 & 2 & 0.2 & ND & $r$ & $\mathrm{PF}$ & Z \\
\hline Renda sp.1 & 2 & 0.2 & ND & $r$ & $\mathrm{PF}$ & Z \\
\hline Staphylinidae ind.7 & 2 & 0.2 & ND & $r$ & PF & Z \\
\hline Staphylinidae ind.4 & 2 & 0.2 & ND & r & $\mathrm{PF}$ & Z \\
\hline Xanthopygus cyanelytrius (Perty, 1830) & 1 & 0.1 & ND & $r$ & $\mathrm{PF}$ & Z \\
\hline Staphylinidae ind.11 & 1 & 0.1 & ND & $r$ & $\mathrm{PF}$ & Z \\
\hline Staphylinidae ind.12 & 1 & 0.1 & ND & $r$ & $\mathrm{PF}$ & Z \\
\hline Staphylinidae ind.6 & 1 & 0.1 & ND & $r$ & $\mathrm{PF}$ & Z \\
\hline Paederus sp. 1 & 1 & 0.1 & ND & $r$ & PF & Z \\
\hline Lathropinus torosus (Erichson, 1840) & 1 & 0.1 & ND & r & $\mathrm{PF}$ & Z \\
\hline Staphylinidae ind.13 & 1 & 0.1 & ND & $r$ & PF & Z \\
\hline Staphylinidae ind.14 & 1 & 0.1 & ND & $r$ & PF & Z \\
\hline Staphylinidae ind.15 & 1 & 0.1 & ND & $r$ & $\mathrm{PF}$ & Z \\
\hline Staphylinidae ind.16 & 1 & 0.1 & ND & $r$ & $\mathrm{PF}$ & Z \\
\hline Staphylinidae ind.17 & 1 & 0.1 & ND & $r$ & $\mathrm{PF}$ & Z \\
\hline Staphylinidae ind.18 & 1 & 0.1 & ND & $r$ & $\mathrm{PF}$ & Z \\
\hline Staphylinidae ind.19 & 1 & 0.1 & ND & $r$ & $\mathrm{PF}$ & Z \\
\hline Staphylinidae ind.20 & 1 & 0.1 & ND & $r$ & $\mathrm{PF}$ & Z \\
\hline Staphylinidae ind.21 & 1 & 0.1 & ND & $r$ & PF & Z \\
\hline Staphylinidae ind.8 & 1 & 0.1 & ND & $r$ & $\mathrm{PF}$ & Z \\
\hline Staphylinidae ind.22 & 1 & 0.1 & ND & $r$ & PF & Z \\
\hline Total Staphylinidae & 203 & 20.2 & & & & \\
\hline
\end{tabular}

D: dominant, ND: not dominant; ma: very abundant, a: abundant, c: common, d: dispersed, r: rare; MF: very frequent, F: frequent, PF: little frequent; W: constant, Y: incidental, Z: accidental. Species ind: indeterminate species.

Table 2. Carabidae and Staphylinidae collected in areas of forest fragment and soybean crop in conventional tillage system according to dominance (D), abundance (A), frequency (F) and constancy (C). Guaíra county, State of São Paulo, Brazil - 2004/2007

\begin{tabular}{|c|c|c|c|c|c|c|}
\hline Especies/Family & Number of specimens & $\%$ & D & A & $\mathbf{F}$ & C \\
\hline \multicolumn{7}{|l|}{ Carabidae } \\
\hline Scarites sp. 1 & 471 & 43.9 & SD & sa & SF & W \\
\hline Abaris basistriata & 292 & 27.2 & SD & sa & SF & W \\
\hline Odontocheila nodicornis & 59 & 5.5 & $\mathrm{D}$ & ma & MF & W \\
\hline Calosoma granulatum & 55 & 5.1 & $\mathrm{D}$ & ma & MF & W \\
\hline Loxandrus sp.1 & 27 & 2.5 & $\mathrm{D}$ & $\mathrm{ma}$ & MF & W \\
\hline Selenophorus seriatoporus & 21 & 2.0 & $\mathrm{D}$ & $\mathrm{ma}$ & MF & $\mathrm{Y}$ \\
\hline Lebiini sp.2 & 11 & 1.0 & $\mathrm{D}$ & $\mathrm{ma}$ & MF & Y \\
\hline Carabidae ind.12 & 8 & 0.7 & $\mathrm{D}$ & $c$ & $\mathrm{~F}$ & $\mathrm{Y}$ \\
\hline Tetragonoderus laevigatus & 6 & 0.6 & D & c & $\mathrm{F}$ & $\mathrm{Y}$ \\
\hline Stratiotes sp. 1 & 5 & 0.5 & ND & c & $\mathrm{F}$ & $\mathrm{Y}$ \\
\hline Selenophorus alternans & 5 & 0.5 & ND & c & $\mathrm{F}$ & $\mathrm{Y}$ \\
\hline Megacephala brasiliensis & 5 & 0.5 & ND & c & $\mathrm{F}$ & $\mathrm{Y}$ \\
\hline Carabidae ind.14 & 4 & 0.4 & ND & c & $\mathrm{F}$ & $\mathrm{Y}$ \\
\hline Carabidae ind.13 & 4 & 0.4 & ND & c & $\mathrm{F}$ & $\mathrm{Y}$ \\
\hline Morion cycloma Chaudoir, 1854 & 3 & 0.3 & ND & c & $\mathrm{F}$ & $\mathrm{Y}$ \\
\hline Galerita brasiliensis Dejean, 1826 & 3 & 0.3 & ND & c & $\mathrm{F}$ & Y \\
\hline Sphalera plaumanni & 3 & 0.3 & ND & c & $\mathrm{F}$ & $\mathrm{Y}$ \\
\hline Loxandrus sp.2 & 3 & 0.3 & ND & c & $\mathrm{F}$ & $\mathrm{Y}$ \\
\hline Tichonilla festiva & 2 & 0.2 & ND & d & PF & Z \\
\hline Cymindis sp. 1 & 2 & 0.2 & ND & d & PF & Z \\
\hline Loxandrus subvittatus & 2 & 0.2 & ND & d & $\mathrm{PF}$ & Z \\
\hline
\end{tabular}


Table 2. Continuation

\begin{tabular}{|c|c|c|c|c|c|c|}
\hline Especies/Family & Number of specimens & $\%$ & D & A & $\mathbf{F}$ & C \\
\hline Scarites sp.3 & 2 & 0.2 & ND & d & PF & Z \\
\hline Carabidae ind.15 & 2 & 0.2 & ND & d & PF & Z \\
\hline Colliuris brasiliensis & 1 & 0.1 & ND & $r$ & PF & Z \\
\hline Athrostictus nobilis (Brulle, 1838) & 1 & 0.1 & ND & $r$ & PF & Z \\
\hline Notiobia sp.2 & 1 & 0.1 & ND & $r$ & PF & Z \\
\hline Lebiini sp.1 & 1 & 0.1 & ND & $r$ & PF & Z \\
\hline Lebiini sp.3 & 1 & 0.1 & ND & $r$ & PF & Z \\
\hline Carabidae ind.17 & 1 & 0.1 & ND & $r$ & PF & Z \\
\hline Carabidae ind.16 & 1 & 0.1 & ND & $r$ & PF & Z \\
\hline Pentacomia cupricollis & 1 & 0.1 & ND & $r$ & PF & Z \\
\hline Pseudaptirus albicornis & 1 & 0.1 & ND & $r$ & PF & Z \\
\hline Carabidae ind. 8 & 1 & 0.1 & ND & $r$ & PF & Z \\
\hline Lebia concinna Brulle, 1838 & 1 & 0.1 & ND & $r$ & PF & Z \\
\hline Carabidae ind.18 & 1 & 0.1 & ND & $r$ & PF & Z \\
\hline Notiobia cupripennis (Germar, 1824) & 1 & 0.1 & ND & $r$ & PF & Z \\
\hline Carabidae ind.19 & 1 & 0.1 & ND & $r$ & PF & Z \\
\hline Pterostichini sp.2 & 1 & 0.1 & ND & $r$ & $\mathrm{PF}$ & Z \\
\hline Total Carabidae & 1010 & 94.1 & & & & \\
\hline \multicolumn{7}{|l|}{ Staphylinidae } \\
\hline Smilax pilosa & 14 & 1.3 & $\mathrm{D}$ & $\mathrm{ma}$ & MF & $Y$ \\
\hline Staphylinidae ind.3 & 11 & 1.0 & $\mathrm{D}$ & $\mathrm{ma}$ & MF & $Y$ \\
\hline Xantholinini sp.1 & 11 & 1.0 & $\mathrm{D}$ & $\mathrm{ma}$ & MF & Y \\
\hline Staphylinidae ind.23 & 3 & 0.3 & ND & c & $\mathrm{F}$ & $Y$ \\
\hline Xantholinini sp.2 & 3 & 0.3 & ND & $c$ & $\mathrm{~F}$ & $Y$ \\
\hline Staphylinidae ind.26 & 3 & 0.3 & ND & c & $F$ & $Y$ \\
\hline Staphylinidae ind. 12 & 3 & 0.3 & ND & c & $\mathrm{F}$ & Z \\
\hline Glenus chrysis & 2 & 0.2 & ND & d & PF & Z \\
\hline Xenopygus sp.2 & 2 & 0.2 & ND & d & PF & Z \\
\hline Staphylinidae ind.2 & 2 & 0.2 & ND & d & PF & Z \\
\hline Eulissus chalybaeus & 2 & 0.2 & ND & d & $\mathrm{PF}$ & Z \\
\hline Paederus sp. 1 & 1 & 0.1 & ND & $r$ & $\mathrm{PF}$ & Z \\
\hline Scytalinus sp.1 & 1 & 0.1 & ND & $r$ & $\mathrm{PF}$ & Z \\
\hline Staphylinidae ind.24 & 1 & 0.1 & ND & $r$ & PF & Z \\
\hline Staphylinidae ind. 25 & 1 & 0.1 & ND & $r$ & PF & Z \\
\hline
\end{tabular}

D: dominant, ND: not dominant; ma: very abundant, a: abundant, c: common, d: dispersed, r: rare; MF: very frequent, F: frequent, PF: little frequent; W: constant, Y: incidental, Z: accidental. Species ind: indeterminate species.

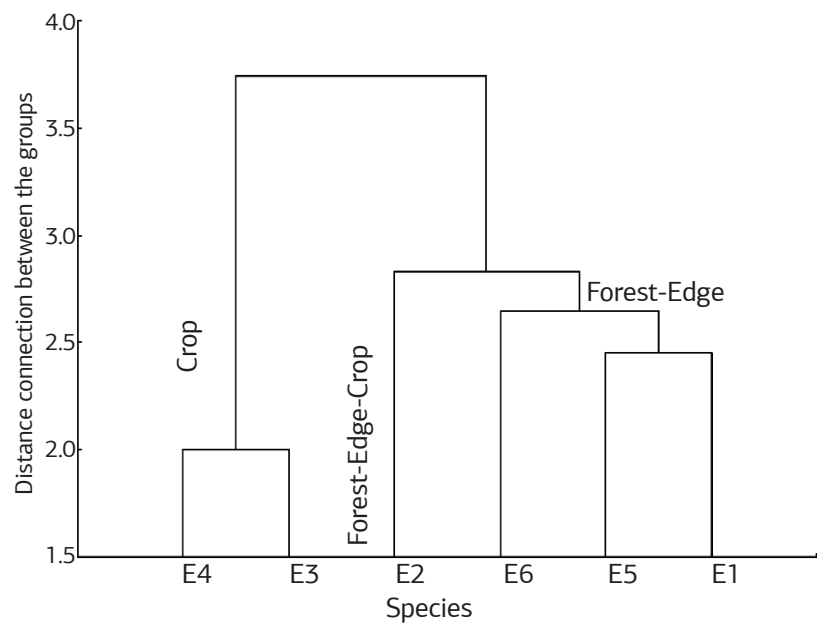

Figure 3. Cluster analysis dendrogram of species Carabidae depending on the position of the trap. Euclidian distance. Conventional tillage system - 2004/2007. E1: Odontocheila nodicornis, E2: Abaris basistriata, E3: Scarites sp.1, E4: Calosoma granulatum, E5: Loxandrus sp.1, E6: Selenophorus seriatuporus.
As discussed previously, Scarites sp. 1 and C. granulatum, P. cupricollis, Scarites sp. 2 and T. brasiliensis showed preference for crops and were collected in the edge and up to 100 meters into the crops. C. granulatum occurred in larger numbers from 50 to 100 meters into the crop in both systems, while $P$. curpicollis was concentrated in the edge (Figures 4 and 5). These results suggest that the edge habitat between the crop and the forest fragments was inhabited by the majority of species, and could have been used as a refuge area or shelter. According to Kromp and Steinberger (1992), Holland and Luff (2000) and Altieri et al. (2003), crop marginal areas can shelter natural enemies when the conditions of the crop are adverse due to cultural practices.

The staphylinids E. chalybaeus, Xantholinini sp.1 and Staphylinidae ind.2 preferred the crops and were distributed up to 100 meters into the crop. These 
species were observed in higher numbers in the edge, while Xantholinini sp. 1 was more numerous starting from $20 \mathrm{~m}$ into the crop (Figure 6).
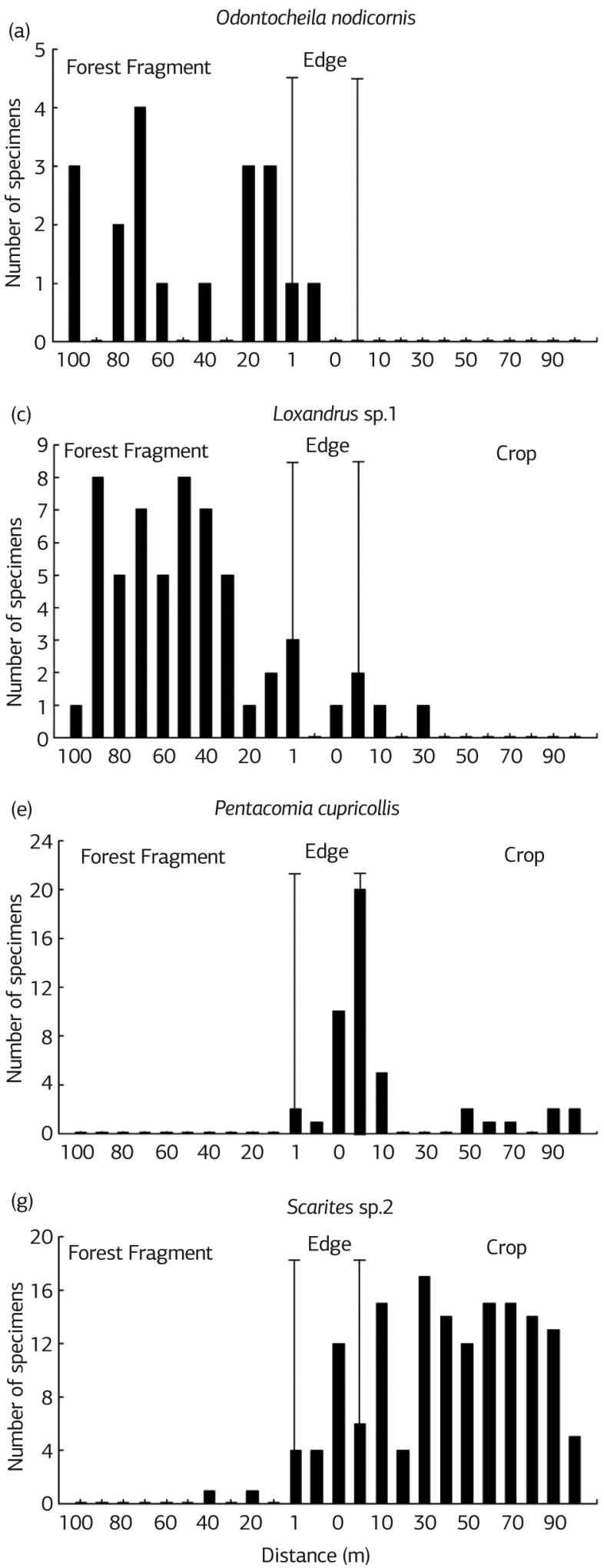

Some ground beetles can move long distances as they search for prey (Thomas et al., 1997; Zhang et al., 1997; Horgan and Chávez, 2004). In the

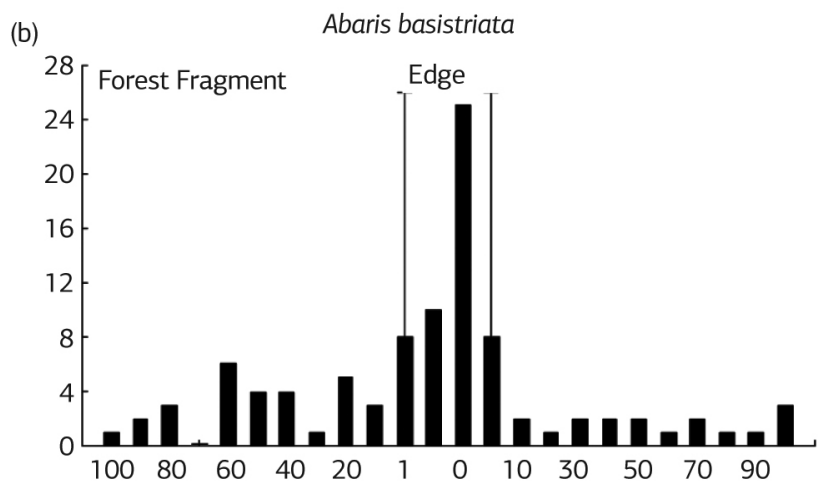

(d)

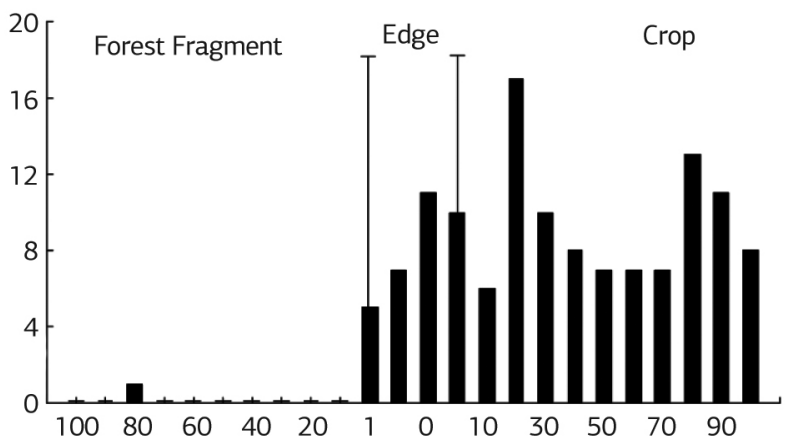

(f)

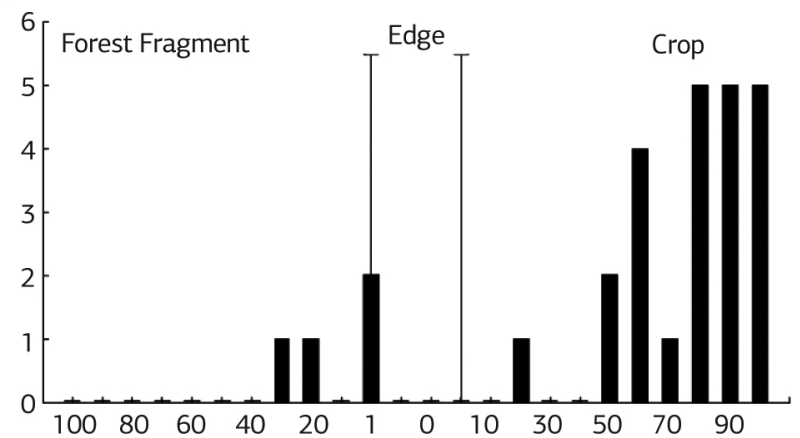

(h)

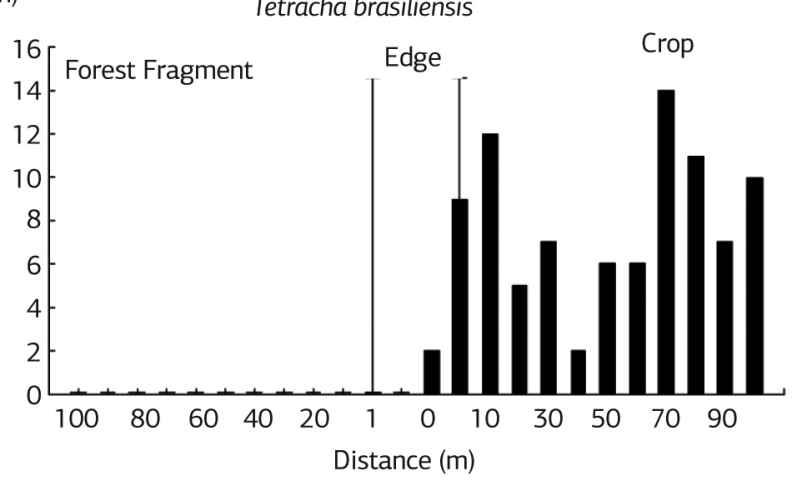

Figure 4. Total number of specimens and horizontal distribution of Carabidae: (a) Odontocheila nodicornis; (b) Abaris basistriata; (c) Loxandrus sp.1; (d) Scarites sp.1; (e) Pentacomia cupricollis; (f) Calosoma granulatum; (g) Scarites sp.2; (h) Tetracha brasiliensis, in the tree habitats: Forest fragment, edge (weeds) and crop (rotation soybean/corn). Experimental area: No-tillage system - 2004/2007. 
(a)

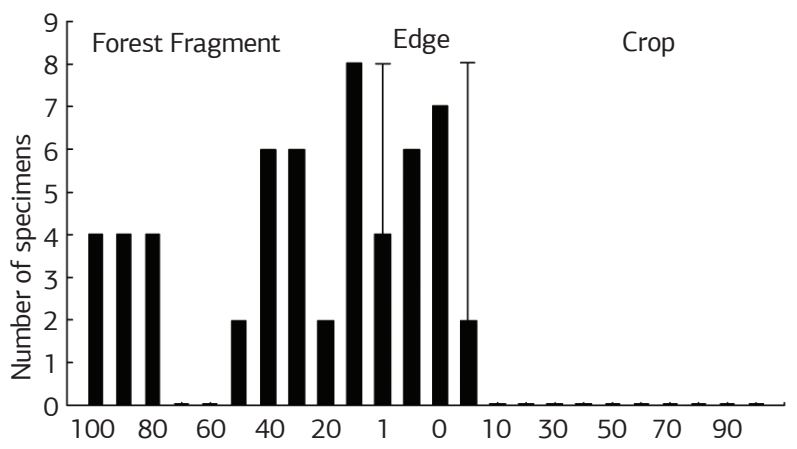

(c)

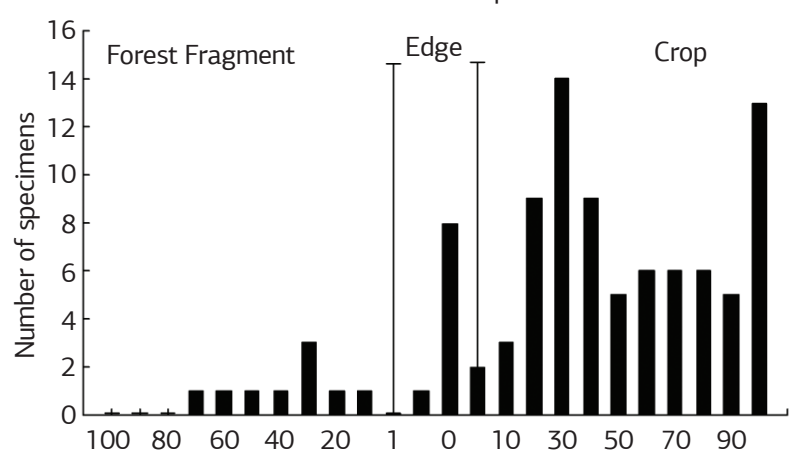

(e)

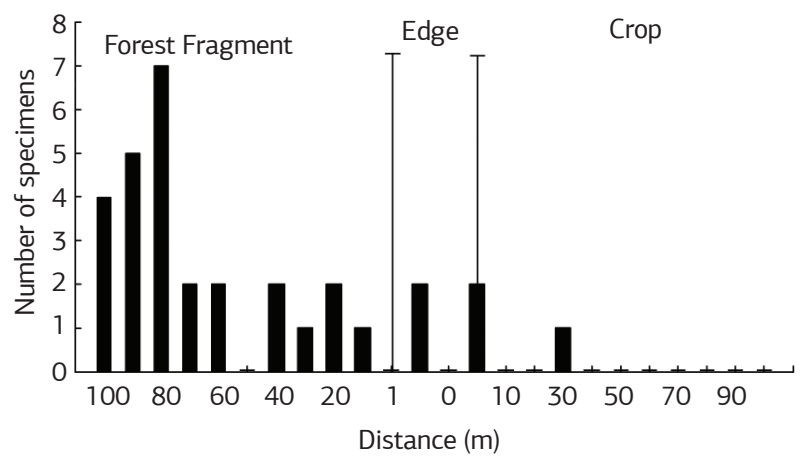

(b)

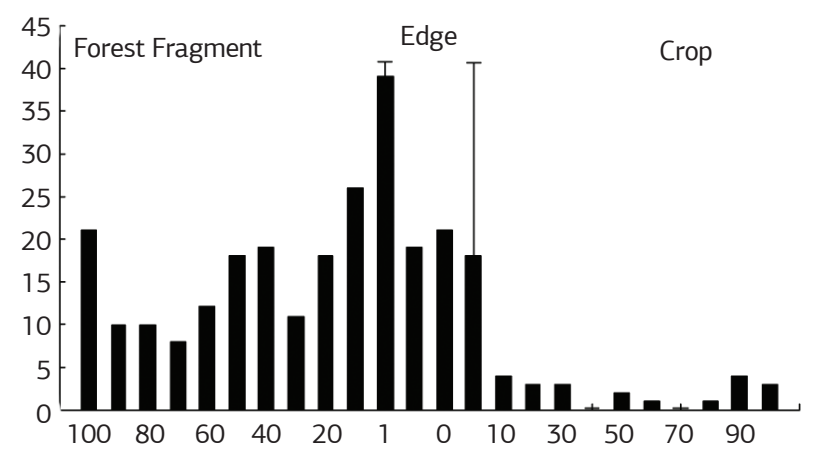

(d)

Calosoma granulatum

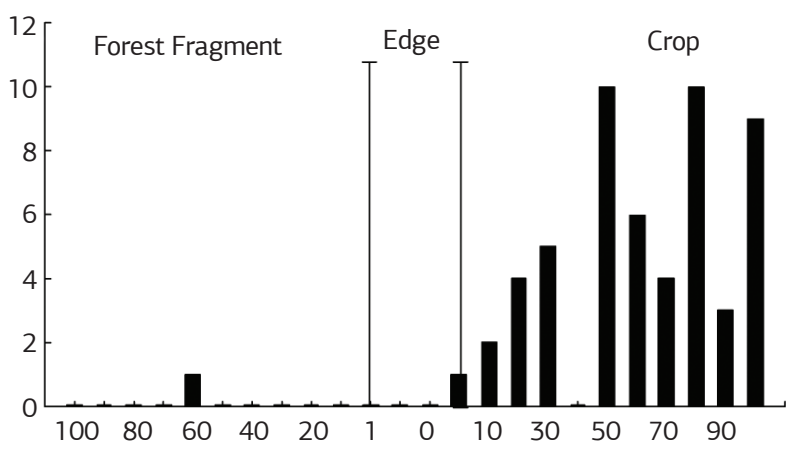

(f) Selenophorus seriatoporus

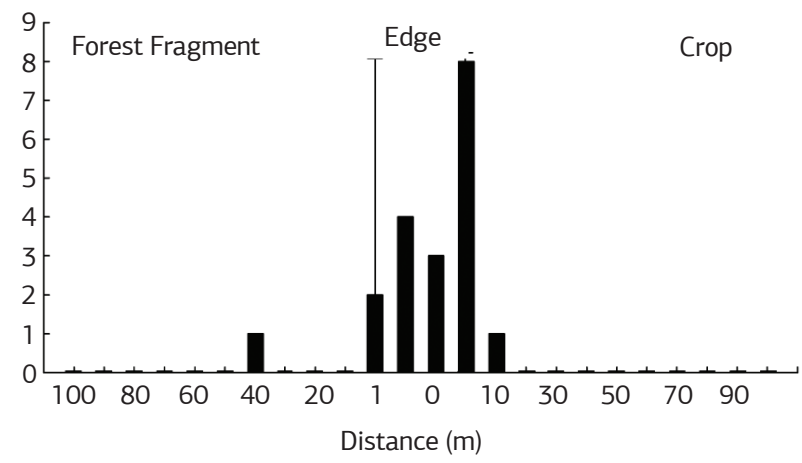

Figure 5. Total number of specimens and horizontal distribution of Carabidae: (a) Odontocheila nodicornis; (b) Abaris basistriata; (c) Scarites sp.1; (d) Calosoma granulatum; (e) Loxandrus sp.1; (f) Selenophorus seriatoporus, in the tree habitats: Forest fragment, edge (weeds) and crop (rotation soybean/corn). Experimental area: No-tillage system - 2004/2007.

present study, the distribution of ground beetles and rove beetles in the three habitats suggest that they have the potential to move great distances inside and out of the crop.

\section{CONCLUSION}

The area with no-till and largest forest fragment has a higher diversity of Carabidae and Staphylinidae species when compared with the area of conventional tillage. The carabids Scarites sp.1, Abaris basistriata, Odontocheila nodicornis, Calosoma granulatum and Loxandrus sp. 1 are dominant species in soybean/corn agroecosystems. Abaris basistriata is a generalist species in relation to the type of habitat, unlike other species of Carabidae occurring preferentially in agricultural or natural areas.

\section{ACKNOWLEDGEMENTS}

This research was funded by the Fundação de Amparo à Pesquisa do Estado de Sáo Paulo (FAPESP) and the Conselho Nacional de Desenvolvimento Científico e Tecnológico (CNPq). We thank CNPq by the master degree scholarship provided for the first author and PQ scholarship provided for the second author. 

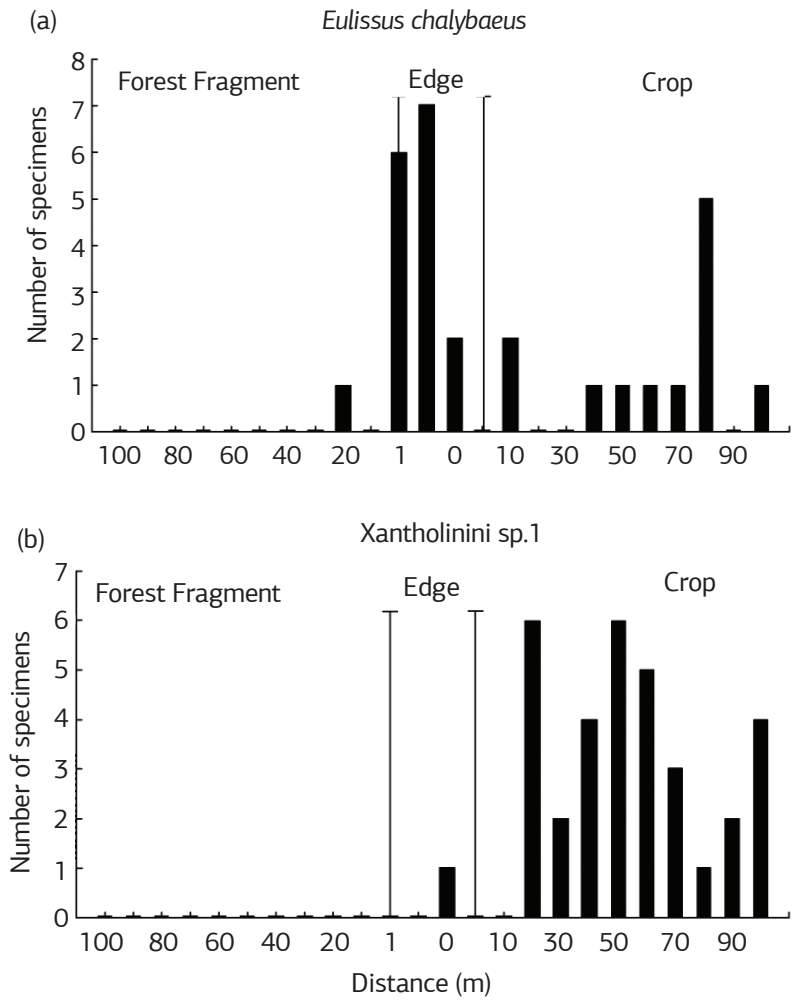

(c)

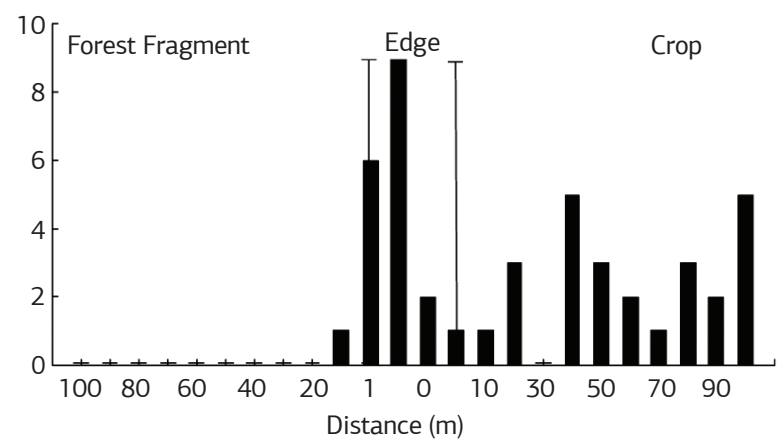

Figure 6. Total number of specimens and horizontal distribution of Staphylinidae: (a) Eulissus chalybaeus; (b) Xantholinini sp.1; (c) Staphylinidae ind.2, in the tree habitats: Forest fragment, edge (weeds) and crop (rotation soybean/corn). Experimental area: Notillage system - 2004/2007.

\section{REFERENCES}

ALTIERI, M.A.; SILVA, N.E.; NICHOLLS, C.I. O papel da biodiversidade no manejo de pragas. Ribeirão Preto: Holos, 2003. 226p.

BEDFORD, S.E.; USHER, M.B. Distribution of arthropod species across the margins of farm woodlands. Agriculture, Ecosystems and Environment, v.48, p.295-305, 1994.

BELLINI, M.R.; MORAES, G.J.; FERES, J.F. Weeds as alternative substrates to phytoseiids (Acari, Phytoseiidae) in rubber tree Hevea brasilienis, Muell. Arg. (Euphorbiaceae) cultivation. Revista Brasileira de Zoologia, v.22, p.35-42, 2005.

CLARK, M.S.; GAGE, S.H.; SPENCER, J.R. Habitats and management associated with common ground beetles (Coleoptera:
Carabidae) in a Michigan agricultural landscape. Environmental Entomology, v.26, p.519-527, 1997.

COLLINS, K.L.; BOATMAN, N.D.; WILCOX, A.; HOLLAND, J.M. A 5-year comparison of overwintering polyphagous predator densities within a beetle bank and two conventional hedgebanks. Annals of Applied Biology, v.143, p.63-71, 2003.

COLLINS, K.L.; BOATMAN, N.D.; WILCOX, A.; HOLLAND, J.M.; CHANEY, K. Influence of beetle banks on cereal aphid predation in winter wheat. Agriculture, Ecosystems and Environment, v.93, p.337-350, 2002.

COOMBES, D.S.; SOTHERTON, N.W. The dispersal and distribution of polyphagous predatory Coleoptera in cereals. Annals of Applied Biology, v.108, p.461-474, 1986.

CURRY, J.P. Grassland Invertebrates: ecology, influence on soil fertility and effects on plant growth. London: Chapman and Hall, 1993, 424p.

DEMITE, P.R.; FERES, R.J.F. Influência de vegetação vizinha na distribuição de ácaros em seringal (Hevea brasiliensis Muell. Arg., Euphorbiaceae) em São José do Rio Preto, SP. Neotropical Entomology, v.34, p.829-836, 2005.

DENNIS, P.; FRY G.L.A. Field margins: can they enhance natural enemy population densities and general arthropod diversity on farmland? Agriculture, Ecosystems and Environment, v.40, p.95-115, 1992.

EDWARDS, C.A.; SUNDERLAND, K.D.; GEORGE, K.S. Studies of polyphagous predators of cereal aphids. Journal of Applied Ecology, v.16, p.811-823, 1979.

EKSCHMITT, K.; WEBER, M.; WOLTERS, V. Spiders, carabids, and staphylinids: the ecological potential of predatory macroarthropods. In: BENCKISER, G. (Ed.). Fauna in Soil Ecosystems. New York: Marcel Dekker, 1997. p.307-362.

FADINI, M.A.M.; REGINA, M.A.; FRAGUAS, J.C.; LOUZADA, J.N.C. Efeito da cobertura vegetal do solo sobre a abundância e diversidade de inimigos naturais de pragas em vinhedos. Revista Brasileira de Fruticultura, v.23, p.573-576, 2001.

FIEDLER, A.K.; LANDIS, D.A. Attractiveness of Michigan native plants to arthropod natural enemies and herbivores. Environmental Entomology, v.36, p.751-765, 2007.

FOURNIER, E.; LOREAU, M. Effects of newly planted hedges on ground-beetle (Coleoptera: Carabidae) in an agricultural landscape. Ecography, v.22, p.87-97, 1999.

FRENCH, B.W.; ELLIOTT, N.C. Temporal and spatial distribution of ground beetle (Coleoptera: Carabidae) assemblages in grasslands and adjacent wheat fields. Pedobiologia, v.43, p.73-84, 1999.

GONÇALVES, P.A.S.; SOUZA-SILVA, C.R. Efeito de espécies vegetais em bordadura em cebola sobre a densidade populacional de tripes e sirfídeos predadores. Horticultura Brasileira, v.21, p.731-734, 2003.

HOLLAND, J.M.; PERRY, J.N.; WINDER, L. The within-field spatial and temporal distribution of arthropods in winter wheat. Bulletin of Entomological Research, v.89, p.499-513, 1999. 
HOLLAND, J.M.; LUFF, M.L. The effects of agricultural practices on Carabidae in temperate agroecosystems. Integrated Pest Management Reviews, v.5, p.109-129, 2000.

HORGAN, F.G.; CHÁVEZ, J.C. Field boundaries restrict dispersal of a tropical tiger beetle, Megacephala angustata Chevrolat 1841 (Coleoptera; Cicindelidae). Entomotropica, v.19, p.147-152, 2004.

HOUSE, G.J.; STINNER, B.R. Arthropods in no-tillage soybean agroecosystems: community composition and ecosystem interactions. Environmental Management, v.7, p.23-28, 1983.

KREBS, C.J. Ecological methodology. 2.ed. Boston: Addison Wesley Longman, 1999. 620p.

KROMP B.; STEINBERGER, K.H. Grassy field margins and arthropod diversity: a case study on ground beetles and spiders in eastern Austria (Coleoptera: Carabidae, Arachnida: Aranei, Opiliones). Agriculture, Ecosystems and Environment, v.40, p.71-93, 1992.

KROMP, B. Carabid beetle communities (Carabidae, Coleoptera) in biologically and conventionally farmed agroecosystems. Agriculture, Ecosystems and Environment, v.27, p.241-251, 1989 .

KROMP, B. Carabid beetles in sustainable agriculture: a review on pest control efficacy, cultivation impacts and enhancement. Agriculture, Ecosystems and Environment, v.74, p.187-228, 1999 .

LANG, A.; FILSER, J.; HENSCHEL, J.R. Predation by ground beetles and wolf spiders on herbivorous insects in a maize crop. Agriculture, Ecosystems and Environment, v.72, p.189-199, 1999.

MACEDO, J.F.; MARTINS, R.P. Potencial da erva daninha Waltheria americana (Sterculiaceae) no manejo integrado de pragas e polinizadores: visitas de abelhas e vespas. Anais da Sociedade Entomológica do Brasil, v.27, p.29-40, 1998.

PFIFFNER, L.; LUKA, H. Overwintering of arthropods in soils of arable fields and adjacent semi-natural habitats. Agriculture, Ecosystems and Environment, v.78, p.215-222, 2000.
PICHANCOURT, J.B.; BUREL, F.; AUGER, P. Assessing the effect of habitat fragmentation on population dynamics: an implicit modelling approach. Ecological Modelling, v.192, p.543-556, 2006.

SILVEIRA NETO, S.; MONTEIRO, R.C.; ZUCCHI, R.A.; MORAES, R.C.B. Uso da análise faunística de insetos na avaliação do impacto ambiental. Scientia Agricola, v.52, p.9-15, 1995.

SILVEIRA, L.C.P.; BUENO, V.H.P.; LOUZADA, J.N.C.; CARVALHO, L.M. Percevejos predadores (Orius spp.) (Hemiptera: Anthocoridae) e tripes (Thysanoptera): interação no mesmo habitat? Revista Árvore, v.29, p.767-773, 2005.

THIELE, H.U. Carabid beetles in their environments. Berlin: Springer, 1977. 369p.

THOMAS, C.F.G.; HOLLAND, J.M.; BROWN, N.J. The spatial distribution of carabid beetles in agricultural landscapes. In: HOLLAND, J.M. Ed. The agroecology of carabid beetles. Andover: Intercept, 2002. p.305-344.

THOMAS, C.F.G.; GREEN, F.; MARSHALL, E.P.J. Distribution, dispersal and population size of the ground beetles, Pterostichus melanarius and Harpalus rufipes (Coleoptera, Carabidae), in fieldmargin habitats. Biological Agriculture and Horticulture, v.15, p.337-352, 1997.

THOMAS, M.B.; WRATTEN, S.D.; SOTHERTON, N.W. Creation of "island" in farmland to manipulate populations of beneficial arthropods: predator densities and emigration. Journal of Applied Ecology, v.28, p.906-917, 1991.

THOMAZINI, M.J.; THOMAZINI, A.P.B.W. A fragmentação florestal e a diversidade de insetos nas florestas tropicais úmidas. Rio Branco: Embrapa Acre, 2000. 21p. (Embrapa Acre, Documentos, 57)

WEIBULL, A.C.; ÖSTMAN, Ö. Species composition in agroecosystems: the effect of landscape, habitat, and farm management. Basic and Applied Ecology, v.4, p.349-361, 2003.

ZHANG, J.; DRUMMOND, F.A.; LIEBMAN, M.; HARTKE, A. Phenology and dispersal of Harpalus rufipes DeGeer (Coleoptera: Carabidae) in agroecosystems in Maine. Journal of Agricultural Entomology, v.14, p.171-186, 1997. 